\title{
Flea and ticks species from dogs in urban and rural areas in four districts in Chile
}

\author{
Pulgas y garrapatas en perros urbanos y rurales en cuatro regiones en Chile
}

\author{
K Abarca ${ }^{\mathrm{a}, \mathrm{b}}$, D Gárate ${ }^{\mathrm{c}}, \mathrm{J}$ López $^{\mathrm{d}}$, G Acosta-Jamett ${ }^{\mathrm{e}}$
}

\begin{abstract}
Fleas and ticks frequently parasitise canines worldwide and their prevalence in dogs is influenced by many factors including climate and geography, among others. Different studies worldwide have shown no clear pattern of an urban or rural preference by different species of fleas and ticks infesting dogs. The aim of this study is to identify species of fleas and ticks present in urban and rural dogs from different ecoregions of Chile. A cross-sectional study was conducted in four urban-rural paired sites at four districts: Arica y Parinacota, Coquimbo, Metropolitana and Araucanía. A random and a convenience sampling of households in the urban and rural areas was carried out, collecting fleas and ticks from 112-114 dogs per locality. The frequency of fleas and ticks infestation between urban and rural areas was compared through Chi-square or Fisher's tests. A total of 921 dogs were examined, identifying four species of fleas (Ctenocephalides canis, Ctenocephalides felis, Pulex irritans and Echidnophaga gallinacea) and three species of ticks (Rhipicephalus sanguineus, Amblyomma tigrinum and Amblyomma triste). In general, a higher prevalence of dogs with fleas were observed in rural areas, being $C$. canis the most frequent species globally; there were significant variations in the distribution of different species according to district. $R$. sanguineus was the predominant tick in all the studied areas. Amblyomma species were found exclusively in rural areas; A. triste only in Arica y Parinacota and A. tigrinum in rural areas of Coquimbo and Araucanía districts.

Key words: ticks, fleas, dogs, urban and rural areas.
\end{abstract}

RESUMEN. Pulgas y garrapatas parasitan frecuentemente a caninos y su prevalencia se asocia a diversos factores incluyendo clima y geografía, entre otros. Diversos estudios han mostrado que no existe una clara preferencia entre sitios urbanos o rurales para las especies de pulgas y garrapatas que infectan perros. El objetivo de este estudio fue identificar especies de pulgas y garrapatas presentes en perros de zonas urbanas y rurales de diferentes ecorregiones de Chile. Se realizó un muestreo transversal en áreas urbanorural de cuatro regiones de Chile: Arica y Parinacota, Coquimbo, Metropolitana y La Araucanía. En ciudades se realizó un muestreo estratificado y en zonas rurales un muestreo por conveniencia para muestrear pulgas y garrapatas de 112-114 perros por localidad. Se comparó la prevalencia de infestación entre urbano y rural por región mediante pruebas de Chi-cuadrado o Fisher. En total 921 perros fueron examinados, identificándose cuatro especies de pulgas (Ctenocephalides canis, Ctenocephalides felis, Pulex irritans y Echidnophaga gallinacea) y tres especies de garrapatas (Rhipicephalus sanguineus, Amblyomma tigrinum y Amblyomma triste). En general, se detectó un mayor número de perros con pulgas en zonas rurales, siendo $C$. canis la especie más frecuente; por otro lado, se detectó una diferencia en la distribución de las especies de acuerdo con el área estudiada. $R$. sanguineus fue la garrapata predominante en todas las áreas de estudio. Garrapatas del género Amblyomma se detectaron exclusivamente en áreas rurales; encontrándose A. triste solo en Arica y Parinacota y A. tigrinum en áreas rurales de las regiones de Coquimbo y La Araucanía.

Palabras clave: garrapatas, pulgas, perros, áreas urbanas y rurales.

\section{INTRODUCTION}

Ectoparasites of pets, as fleas and ticks, are nowadays recognised as able to host and transmit diverse infectious agents to both pets and humans (Hugh-Jones et al 2000, Shaw et al 2001). Fleas and ticks are widely distributed in the world, showing big adaptability and strong resistance

\footnotetext{
Accepted: 15.10.2015.
}

aDepartamento de Enfermedades Infecciosas e Inmunología Pediátrica, Facultad de Medicina, Pontificia Universidad Católica de Chile, Santiago, Chile.

bLaboratorio de Infectología y Virología Molecular, Pontificia Universidad Católica de Chile, Santiago, Chile.

${ }^{c} F a c u l t a d$ de Ciencias Veterinarias y Pecuarias, Universidad de Chile, Santiago, Chile.

${ }^{\mathrm{d}}$ Hospital Veterinario Puente Alto, Santiago, Chile.

eInstituto de Medicina Preventiva Veterinaria y Programa de Investigación Aplicada de Fauna Silvestre, Facultad de Ciencias Veterinarias, Universidad Austral de Chile. Valdivia, Chile.

*Corresponding author: G Acosta-Jamett; gerardo.acosta@uach.cl to different climatic conditions (Durden and Hinkle 2009, Dantas-Torres 2010).

Fleas and ticks are the arthropods that most frequently parasitise canines worldwide, despite the increased availability of drugs to control them (Otranto and Wall 2008). There are several studies worldwide indicating that the presence of ectoparasites could be influenced by the environment in which they are found, for example species of fleas and ticks have been found mostly in rural areas where they can find adequate conditions for their maintenance (Beck et al 2006, Gracia et al 2008, Farkas et al 2009, Debárbora et al 2011). Other studies have reported that dogs inhabiting urban sites are more parasitised by fleas or ticks than those from rural sites (eg. Dantas-Torres 2010).

The flea species Ctenocephalides canis, Ctenocephalides felis, Pulex irritans and Echidnophaga gallinacea have been described in Chile as infesting dogs (Alcaíno and Gorman 1999). C. felis has been reported as the flea that most commonly parasitises canines in Santiago. 
On the other hand, tick species described in domestic dogs in the country are Rhipicephalus sanguineus (Tagle 1976), Amblyomma tigrinum (Tagle 1971) and recently Amblyomma triste (Abarca et al 2012). Unlike fleas, which can be found throughout Chile, ticks have a more specific geographic distribution. A. tigrinum has been reported in Pirque and Santiago (Metropolitan District) (Abarca et al 2013), Nahuelbuta National Park (Araucanía District), Arauco, Concepción (Biobío District), Valparaíso and Santo Domingo (Valparaíso District) (González-Acuña and Guglielmone 2005); R. sanguineus can be found from Viña del Mar (Valparaíso District) (Alcaíno 1985), to Concepción (Biobío District) (Muñoz and Casanueva 2002, González-Acuña and Guglielmone 2005) and Aysén District (Mastropaolo et al 2008); and Amblyomma triste was first found in rural areas near the city of Arica (Abarca et al 2012).

$R$. sanguineus is a tick found mainly in urban areas (Dantas-Torres 2010), whereas species of the genus Amblyomma are mainly found in rural areas because they have wildlife hosts, especially during their larval and nymphal stages, being found in dogs only during their adult stage (Debárbora et al 2011). On the other hand, $R$. sanguineus is more associated with urban areas, and it is expected that canids from rural areas close to them might be more likely to be infested by this tick. Moreover, if $A$. tigrinum is present mainly in rural areas, then a reverse pattern to that of $R$. sanguineus can be expected, i.e. the domestic dog populations inhabiting rural areas have higher probabilities to be infested with A. tigrinum rather than with $R$. sanguineus. In the case of fleas, a higher infestation has been found in rural areas, attributing this to low access to anti-flea products in these areas (Farkas et al 2009).

This study was part of a project aimed to detect zoonotic pathogens in ticks and fleas infecting dogs in urban and rural areas in regions with different temperature and climate conditions in Chile. This study shows results of the species of fleas and ticks currently present in dogs in Chile and their distribution in four districts with varying patterns of temperature and climate, from the arid further north to the moist southern region. Due to their vectorial potential regarding infectious diseases of great importance to both animals and people, a deeper knowledge of the species distribution is relevant to define more appropriate control measures in urban and rural areas of Chile.

\section{MATERIAL AND METHODS}

The study was conducted in four districts (figure 1), considering the following areas: the city of Arica $\left(18^{\circ} 28\right.$ ' $\mathrm{S}, 70^{\circ} 18^{\prime} \mathrm{W}$ ) and surrounding rural areas in the Arica y Parinacota District, which is located in the far north of the country, with dry climate, extremely arid landscape and scarce vegetation. The city of Arica has 180,879 inhabitants (INE 2005) and an estimated dog population

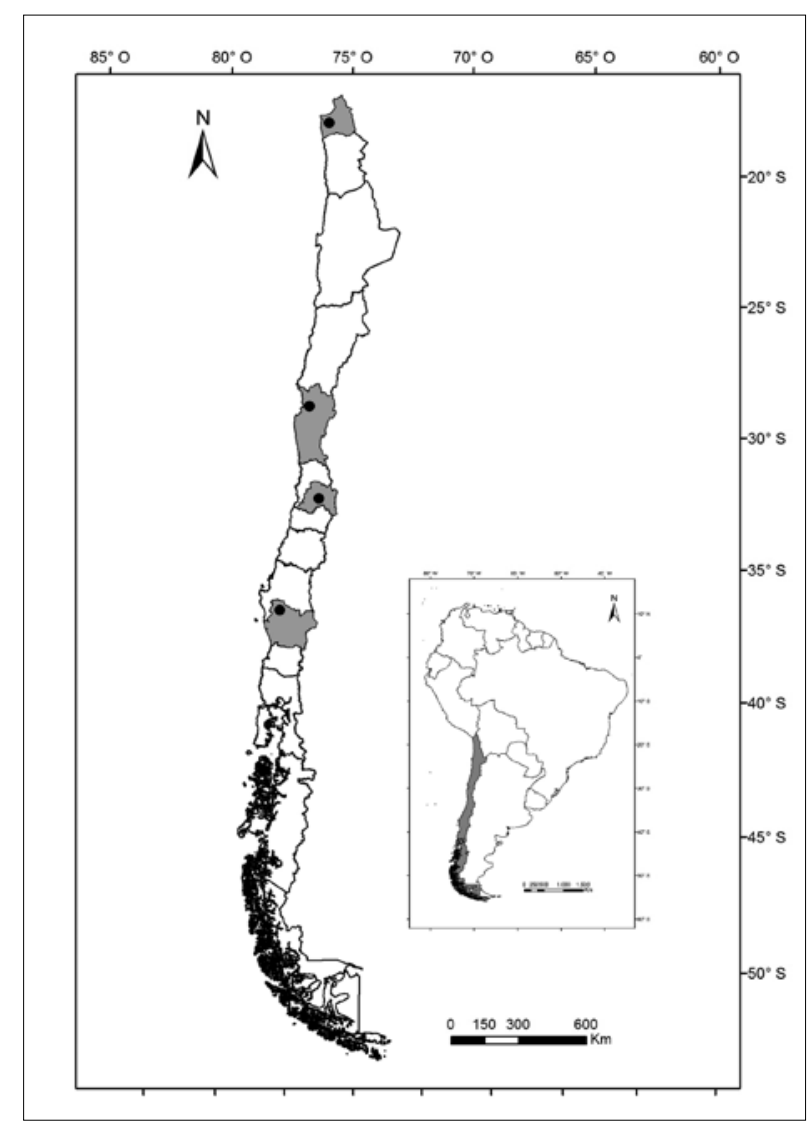

Figure 1. Map of Chile, showing selected areas assessed (black dots) in each studied region (highlighted with gray).

Mapa de Chile indicando las zonas seleccionadas que fueron evaluadas (círculos negros) en cada área de estudio (destacada en gris).

of 32,887 . The city of Coquimbo ( $29^{\circ} 57^{\prime} \mathrm{S}, 71^{\circ} 20^{\prime} \mathrm{W}$ ) and surrounding rural areas in Coquimbo region, with semi-arid climate, a population of 203,036 inhabitants (INE 2005) and an estimated dog population of 36,916. The municipality of Puente Alto (33 $37^{\prime} \mathrm{S} ; 70^{\circ} 34^{\prime} \mathrm{W}$ ), in the Metropolitana District has 492,915 inhabitants (INE 2005) and an estimated population of 111,612 dogs, and in a nearby rural area, the municipality of Pirque, with mediterranean climate and extended dry season. The city of Angol ( $\left.37^{\circ} 48^{\prime} \mathrm{S} ; 72^{\circ} 43^{\prime} \mathrm{W}\right), 42,000$ inhabitants (INE 2005) and an estimated dog population of 7,636, and rural areas between this city and the Nahuelbuta National Park in the Araucanía District, in southern Chile, with transitional climate from humid mild mediterranean to markedly rainy climate. Domestic dog population in urban areas were estimated using a human:dog ratio of 5:1 as reported in the literature (Acosta-Jamett et al 2010). Domestic dog population in rural areas was not estimated due to the difficulty in assessing the inhabitants in the areas to be surveyed.

A cross-sectional study was conducted in the austral spring-summer seasons, when fleas and ticks are more prevalent (Durden and Hinkle 2009, Dantas-Torres 2010) in each study site, thus sampling was carried out 
between September 2010 and January 2011 in Arica y Parinacota, and between October 2011 and February 2012 in the Metropolitana, Coquimbo and Araucanía districts. The sample size was at least 97 households per each area, where one dog per selected household was sampled in each urban and rural area. This sample size was estimated as part of a project aimed to determine the seroprevalence of Anaplasma spp. in Chile. In urban areas, a double stratified random sampling per building block and household was carried out while in rural areas a convenience sampling was performed until the number of pre-established households was completed. Thus a total of 921 dogs were examined, between 112 and 124 per area.

Owners and research assistants manually restrained dogs and during approximately 5 minutes a thorough examination of the whole body of each dog was carried out searching for the presence of adult fleas and ticks. A representative sample of these parasites were obtained. After manual extraction, ectoparasites were preserved in $70 \%$ alcohol until taxonomic analysis. The diagnosis of the species of fleas and ticks was performed by a professional trained in a reference laboratory at the University of São Paulo, Brazil, through observation with a stereoscopic microscope using published taxonomic keys (Pratt and Stojanovich 1966, Barros-Battesti et al 2006).

Presence of ectoparasites per each dog was recorded in Microsoft Excel and mixed infestations were registered. The association between flea and tick species, between cities, and the differences between urban and rural areas were analyzed using chi-square and Fisher exact tests with 95\% confidence, using the software Epi Info 7 (Centers for Disease Control and Prevention, Atlanta).

\section{RESULTS AND DISCUSSION}

Four species of fleas were identified: C. canis, $C$. felis, $P$. irritans and E. gallinacea, with $C$. canis being the most abundant species. Neither $P$. irritans nor $E$. gallinacea were found in the Metropolitana region (table 1). In general, a higher number of dogs with fleas was observed in rural areas, varying according to the studied region, with $C$. canis being more abundant in rural areas of the Coquimbo (66\%) and Metropolitana (29\%) Districts, compared to urban areas

Table 1. Comparison between flea-infested dogs from urban and rural areas, by flea species and studied district.

Comparación de infestación por pulgas en perros de zonas urbanas y rurales, de acuerdo con la especie de pulga y la zona de estudio.

\begin{tabular}{|c|c|c|c|c|c|c|c|c|}
\hline \multirow{2}{*}{ District } & \multicolumn{3}{|c|}{ Urban } & \multicolumn{3}{|c|}{ Rural } & \multirow{2}{*}{$x^{2}$} & \multirow{2}{*}{$\mathrm{P}$} \\
\hline & pos & neg & $\%$ & pos & neg & $\%$ & & \\
\hline \multicolumn{9}{|l|}{ C. canis } \\
\hline Arica y Parinacota & 24 & 89 & 21 & 25 & 87 & 22 & 0.1 & 0.844 \\
\hline Coquimbo & 29 & 85 & 25 & 74 & 38 & 66 & 37.6 & $<0.001$ \\
\hline Metropolitana & 6 & 111 & 5 & 34 & 83 & 29 & 23.6 & $<<0.001$ \\
\hline La Araucanía & 21 & 103 & 17 & 26 & 86 & 23 & 1.5 & 0.227 \\
\hline \multicolumn{9}{|l|}{ C. felis } \\
\hline Arica y Parinacota & 42 & 71 & 37 & 25 & 87 & 22 & 5.9 & 0.015 \\
\hline Coquimbo & 32 & 82 & 28 & 61 & 51 & 54 & 16.3 & $<<0.001$ \\
\hline Metropolitana & 2 & 115 & 2 & 7 & 110 & 6 & 2.9 & 0.089 \\
\hline La Araucanía & 4 & 120 & 3 & 3 & 109 & 3 & 0.1 & 0.804 \\
\hline \multicolumn{9}{|l|}{ P. irritans } \\
\hline Arica y Parinacota & 9 & 104 & 8 & 29 & 83 & 26 & 12.9 & $<<0.001$ \\
\hline Coquimbo & 36 & 78 & 32 & 30 & 82 & 27 & 0.6 & 0.428 \\
\hline Metropolitana & 0 & 117 & 0 & 0 & 117 & 0 & NA & NA \\
\hline La Araucanía & 14 & 110 & 11 & 16 & 96 & 14 & 0.5 & 0.490 \\
\hline \multicolumn{9}{|l|}{ E. gallinacea } \\
\hline Arica y Parinacota & 0 & 113 & 0 & 1 & 111 & 1 & $*$ & 0.498 \\
\hline Coquimbo & 1 & 113 & 1 & 11 & 101 & 10 & $*$ & 0.003 \\
\hline Metropolitana & 0 & 117 & 0 & 0 & 117 & 0 & NA & NA \\
\hline La Araucanía & 0 & 124 & 0 & 1 & 111 & 1 & $*$ & 0.475 \\
\hline
\end{tabular}

Asterisk (*) indicates that Fisher's exact test was performed. 
of the same regions (Coquimbo: $25 \%$ and Metropolitana $5 \%$ ). C. felis was more abundant in rural areas of Coquimbo (54\%) than in the city (28\%), but the opposite was found in Arica y Parinacota (Rural: $22 \%$ and urban: $37 \%$ ). Similarly, P. irritans infestation was also higher in rural (26\%) than urban area (8\%) in Arica y Parinacota region. In general, E. gallinacea was the flea that less affected dogs and was primarily associated with rural areas, however significant differences were only found in the Coquimbo District (table 1).

This study confirms that dogs in Chile are parasitised with the four species of fleas previously described in the country (Alcaíno et al 2002). The results of this study are consistent with those reported worldwide (Alcaíno et al 2002, González et al 2004, Durden et al 2005, Gracia et al 2008, Farkas et al 2009), where the predominant species infecting dogs are C. felis and C. canis. The predominance of $C$. canis or $C$. felis varies in the literature, with C. canis for instance most common in many towns of the Buenos Aires province in Argentina (González et al 2004) and in Osorno in Chile (Alcaíno et al 2002), while C. felis has prevailed in two cities in Chile, Santiago and Concepción (Alcaíno et al 2002).

The presence of $C$. canis and $C$. felis mostly in rural areas is consistent with the findings of other authors who point out that these species prevails in rural areas (Gracia et al 2008, Farkas et al 2009). The high level of flea infestation in rural areas has been previously attributed to the lower income of dog owners from these areas and also the low access to anti-flea products compared to urban areas (Farkas et al 2009). P. irritans was more frequently found in the rural region of Arica and Parinacota, with no differences among other regions. Whether this flea has an urban or rural predilection, it is not clear; for example, in a study in Hungary it was only found in rural areas (Farkas et al 2009), while Gracia et al (2008) reported in Spain that the flea was most commonly found in animals kept in apartments than houses. E. gallinacea is distributed globally and this fleas occur wherever chickens are presents and has been also occasionally reported on dogs and cats (Durden and Hinkle 2009), which is confirmed in this study, where we report its presence mainly in rural areas of three regions, suggesting a common infection among birds and dogs in these areas. Whether the presence of one dog infested with E. gallinacea in Coquimbo could indicate the likely contact of that dog with chickens within the property or in surrounding rural areas, remains unknown.

The results of this study confirm the presence of the three species of ticks previously described in the country (R. sanguineus, A. tigrinum and A. triste). R. sanguineus was the predominant species in all the studied areas, both rural and urban, being significantly more frequent in urban areas of all regions except in Coquimbo District. Amblyomma species were found exclusively in rural areas; A. triste was only found in Arica y Parinacota and A. tigrinum in rural areas of Coquimbo and Araucanía districts (table 2).

Table 2. Comparison between tick-infested dogs from urban and rural areas, according to tick species and studied district. Comparación de infestación por garrapatas en perros de zonas urbanas y rurales, de acuerdo con la especie de garrapata y la zona de estudio.

\begin{tabular}{|c|c|c|c|c|c|c|c|c|}
\hline \multirow{2}{*}{ District } & \multicolumn{3}{|c|}{ Urban } & \multicolumn{3}{|c|}{ Rural } & \multirow{2}{*}{$x^{2}$} & \multirow{2}{*}{$\mathrm{P}$} \\
\hline & pos & neg & $\%$ & pos & neg & $\%$ & & \\
\hline \multicolumn{9}{|l|}{$R$. sanguineus } \\
\hline Arica y Parinacota & 35 & 78 & 31 & 57 & 55 & 51 & 9.2 & 0.002 \\
\hline Coquimbo & 57 & 57 & 50 & 52 & 60 & 46 & 0.3 & 0.591 \\
\hline Metropolitana & 54 & 63 & 46 & 84 & 33 & 72 & 15.9 & $<<0.001$ \\
\hline La Araucanía & 64 & 60 & 52 & 18 & 94 & 16 & 32.8 & $<<0.001$ \\
\hline \multicolumn{9}{|l|}{ A. tigrinum } \\
\hline Arica y Parinacota & 0 & 113 & 0 & 0 & 112 & 0 & NA & NA \\
\hline Coquimbo & 0 & 114 & 0 & 12 & 100 & 11 & $*$ & $<<0.001$ \\
\hline Metropolitana & 0 & 117 & 0 & 0 & 117 & 0 & NA & NA \\
\hline La Araucanía & 0 & 124 & 0 & 8 & 104 & 7 & $*$ & $<0.01$ \\
\hline \multicolumn{9}{|l|}{ A. triste } \\
\hline Arica y Parinacota & 0 & 113 & 0 & 11 & 101 & 10 & $*$ & $<<0.001$ \\
\hline Coquimbo & 0 & 114 & 0 & 0 & 112 & 0 & NA & NA \\
\hline Metropolitana & 0 & 117 & 0 & 0 & 117 & 0 & NA & NA \\
\hline La Araucanía & 0 & 124 & 0 & 0 & 112 & 0 & NA & NA \\
\hline
\end{tabular}

Asterisk (*) indicates that Fisher's exact test was performed. 
Table 3. Mixed species of ectoparasites infestation on dogs from urban and rural areas of four regions in Chile. Infestación múltiple por ectoparásitos en perros de zonas urbanas y rurales en cuatro regiones de Chile.

\begin{tabular}{|c|c|c|c|c|c|c|c|c|c|}
\hline \multirow{3}{*}{ Ectoparasite } & \multicolumn{8}{|c|}{$\mathrm{N}^{\circ}$ of infested dogs (\%) } & \multirow{3}{*}{ Total } \\
\hline & \multicolumn{2}{|c|}{ Arica y Parinacota } & \multicolumn{2}{|c|}{ Coquimbo } & \multicolumn{2}{|c|}{ Metropolitana } & \multicolumn{2}{|c|}{ La Araucanía } & \\
\hline & Urban & Rural & Urban & Rural & Urban & Rural & Urban & Rural & \\
\hline Five species & 0 & $1(1)$ & 0 & $1(1)$ & 0 & 0 & 0 & 0 & $2(1)$ \\
\hline $\mathrm{Rs}+\mathrm{Cc}+\mathrm{Cf}+\mathrm{Pi}+\mathrm{Eg}$ & 0 & 1 & 0 & 1 & 0 & 0 & 0 & 0 & 2 \\
\hline Four species & 0 & 7 (6) & 0 & $4(3)$ & 0 & 0 & 0 & $2(2)$ & $13(1)$ \\
\hline $\mathrm{Rs}+\mathrm{Ati}+\mathrm{Cc}+\mathrm{Cf}$ & 0 & 0 & 0 & 1 & 0 & 0 & 0 & 0 & 1 \\
\hline $\mathrm{Rs}+\mathrm{Ati}+\mathrm{Cc}+\mathrm{Pi}$ & 0 & 0 & 0 & 0 & 0 & 0 & 0 & 1 & 1 \\
\hline $\mathrm{Rs}+\mathrm{Ati}+\mathrm{Cc}+\mathrm{Eg}$ & 0 & 0 & 0 & 1 & 0 & 0 & 0 & 0 & 1 \\
\hline $\mathrm{Rs}+\mathrm{Ati}+\mathrm{Pi}+\mathrm{Eg}$ & 0 & 0 & 0 & 1 & 0 & 0 & 0 & 0 & 1 \\
\hline $\mathrm{Rs}+\mathrm{Atr}+\mathrm{Cc}+\mathrm{Cf}$ & 0 & 2 & 0 & 0 & 0 & 0 & 0 & 0 & 2 \\
\hline $\mathrm{Rs}+\mathrm{Cc}+\mathrm{Cf}+\mathrm{Pi}$ & 0 & 5 & 0 & 0 & 0 & 0 & 0 & 1 & 6 \\
\hline $\mathrm{Rs}+\mathrm{Cc}+\mathrm{Pi}+\mathrm{Eg}$ & 0 & 0 & 0 & 1 & 0 & 0 & 0 & 0 & 1 \\
\hline Three species & $9(8)$ & $13(12)$ & $16(14)$ & $24(21)$ & 0 & $1(1)$ & $7(6)$ & $4(3)$ & $74(8)$ \\
\hline $\mathrm{Rs}+\mathrm{Cc}+\mathrm{Cf}$ & 5 & 3 & 3 & 11 & 0 & 1 & 1 & 1 & 25 \\
\hline $\mathrm{Rs}+\mathrm{Cc}+\mathrm{Pi}$ & 0 & 3 & 7 & 2 & 0 & 0 & 6 & 1 & 19 \\
\hline $\mathrm{Rs}+\mathrm{A} t \mathrm{t}+\mathrm{Cc}$ & 0 & 0 & 0 & 2 & 0 & 0 & 0 & 0 & 2 \\
\hline $\mathrm{Rs}+\mathrm{Cf}+\mathrm{Pi}$ & 1 & 3 & 5 & 1 & 0 & 0 & 0 & 0 & 10 \\
\hline $\mathrm{Ati}+\mathrm{Cc}+\mathrm{Cf}$ & 0 & 0 & 0 & 4 & 0 & 0 & 0 & 0 & 4 \\
\hline $\mathrm{Ati}+\mathrm{Cc}+\mathrm{Pi}$ & 0 & 0 & 0 & 1 & 0 & 0 & 0 & 1 & 2 \\
\hline $\mathrm{Ati}+\mathrm{Cc}+\mathrm{Eg}$ & 0 & 0 & 0 & 0 & 0 & 0 & 0 & 1 & 1 \\
\hline $\mathrm{Ati}+\mathrm{Cf}+\mathrm{Pi}$ & 0 & 0 & 1 & 0 & 0 & 0 & 0 & 0 & 1 \\
\hline $\mathrm{Cc}+\mathrm{Cf}+\mathrm{Pi}$ & 3 & 4 & 0 & 0 & 0 & 0 & 0 & 0 & 7 \\
\hline $\mathrm{Cc}+\mathrm{Cf}+\mathrm{Eg}$ & 0 & 0 & 0 & 1 & 0 & 0 & 0 & 0 & 1 \\
\hline $\mathrm{Cc}+\mathrm{Pi}+\mathrm{Eg}$ & 0 & 0 & 0 & 2 & 0 & 0 & 0 & 0 & 2 \\
\hline Two species & $24(21)$ & $14(12)$ & $25(22)$ & $35(32)$ & $4(3)$ & $30(26)$ & $18(14)$ & $6(5)$ & 156 (17) \\
\hline $\mathrm{Rs}+\mathrm{Cc}$ & 3 & 0 & 2 & 7 & 3 & 25 & 7 & 4 & 51 \\
\hline $\mathrm{Rs}+\mathrm{Cf}$ & 9 & 2 & 7 & 5 & 1 & 5 & 0 & 0 & 29 \\
\hline $\mathrm{Rs}+\mathrm{Pi}$ & 1 & 3 & 6 & 1 & 0 & 0 & 4 & 0 & 15 \\
\hline Ati+Cc & 0 & 0 & 0 & 2 & 0 & 0 & 0 & 2 & 4 \\
\hline $\mathrm{Ati}+\mathrm{Pi}$ & 0 & 0 & 0 & 1 & 0 & 0 & 0 & 0 & 1 \\
\hline Atr $+\mathrm{Pi}$ & 0 & 1 & 0 & 0 & 0 & 0 & 0 & 0 & 1 \\
\hline $\mathrm{Cc}+\mathrm{Cf}$ & 9 & 1 & 5 & 11 & 0 & 0 & 2 & 0 & 28 \\
\hline $\mathrm{Cc}+\mathrm{Pi}$ & 0 & 5 & 1 & 3 & 0 & 0 & 5 & 0 & 14 \\
\hline $\mathrm{Cc}+\mathrm{Eg}$ & 0 & 0 & 0 & 1 & 0 & 0 & 0 & 0 & 1 \\
\hline $\mathrm{Cf}+\mathrm{Pi}$ & 2 & 2 & 4 & 3 & 0 & 0 & 0 & 0 & 11 \\
\hline $\mathrm{Cf}+\mathrm{Eg}$ & 0 & 0 & 0 & 1 & 0 & 0 & 0 & 0 & 1 \\
\hline Total & $33(29)^{\mathrm{a}}$ & $35(31)^{\mathrm{a}}$ & $41(36)^{\mathrm{a}}$ & $64(57)^{\mathrm{c}}$ & $4(3)^{d}$ & $31(27)^{\mathrm{a}}$ & $25(20)^{\mathrm{a}}$ & $12(10)^{\mathrm{d}}$ & $245(27)$ \\
\hline
\end{tabular}

Different letters indicate statistically significant differences $(\mathrm{P}<0.05)$.

Rs: Rhipicephalus sanguineus, Ati: Amblyomma tigrinum, Atr: Amblyomma triste, Cc: Ctenocephalides canis, Cf: Ctenocephalides felis, Pi: Pulex irritans, Eg: Echidnophaga gallinacea.

The presence of $R$. sanguineus was not clearly higher in urban or rural areas; in fact this species predominated in rural areas of Arica y Parinacota and the Metropolitana districts and in Angol, Araucanía District. In scientific literature, $R$. sanguineus is depicted as preferring urban settlements (Dantas-Torres 2010). In fact, some authors have found higher prevalence of $R$. sanguineus in urban than rural areas in Mozambique (Neves et al 2004) and Japan (Shimada et al 2003). Additionally, a study found no dogs positive to $R$. sanguineus in a rural region of the Amazon far from a city (Labruna et al 2000). However, different patterns have been found depending on specific regions 
between and within countries. For instance, Dantas-Torres et al (2009) found 49\% of prevalence in a rural area of Pernambuco, in northeast Brazil. Also, Costa et al (2013) in Maranhão state, also in Brazil, found higher prevalence of $R$. sanguineus in rural than urban areas. In another study, conducted in Sao Paulo state in Brazil, dogs infected with $R$. sanguineus showed a prevalence of $28 \%(\mathrm{n}=102)$ and $18 \%(\mathrm{n}=42)$ in urban and rural areas, respectively (Szabo et al 2001); although numerically different, these prevalence between urban and rural sites did not differ statistically.

The presence of both A. triste and A. tigrinum was confirmed exclusively in rural areas, which is explained by their life cycle that includes immature stages feeding on wild rodents (Cricetidae and Caviidae) and ground forest feeding birds, which is a limitation to its maintenance in urban areas (González-Acuña et al 2004, Nava et al 2006, Mastropaolo et al 2008). The presence of A. triste, in rural areas near Arica had been previously reported (Abarca et al 2012). This species is distributed from southern Mexico to Argentina (Estrada-Peña et al 2005). Several studies in South America found that A. triste occurs in hot and humid habitats, and its immature stages are spent mostly on immature rodents and marsupials (Labruna et al 2003). Phylogenetically A. triste is $99.5 \%$ similar to that found in Uruguay, taxonomic and molecularly identical to that described in Perú (Abarca et al 2012). The latter suggests that it has been introduced from Perú and/or existed in this area from ancient times and they share intermediate wildlife hosts. The infestation of dogs with A. triste is important in terms of public health, because this tick is vector of Rickettsia parkeri, which has been reported in different South American countries such as Uruguay (Venzal et al 2008). Moreover, our group recently reported the presence of Rickettsia andeanae in specimens of A. triste we reported in this study in rural areas of the Arica y Parinacota District (Abarca et al 2012), and also in A. tigrinum ticks in dogs in rural areas of the Coquimbo and Araucanía districts (Abarca et al 2013). Although the zoonotic potential of this bacteria remains unknown, but many Rickettsial species that initially were considered as non-pathogenic, their impact on public health has been detected later (eg. Paddock et al 2004). Therefore, further studies are needed to identify the exact distribution of A. triste and A. tigrinum in Chile and their impact on public health.

Mixed infestation was recorded in all regions and ranged from two to five species. Rural area of the Coquimbo District showed higher mixed infestation while the urban area in Metropolitana region the lowest. On the other hand, rural areas of the Coquimbo and Metropolitana districts showed higher infestation than their corresponding rural site. On the contrary, dogs in Angol, Araucanía District, had higher infestation than dogs in their rural counterpart. Although in Arica y Parinacota a tendency to higher infestation in rural dogs was detected this difference was not statistically significant (table 3). The results of this study partially agree with Costa et al
(2013), who detected higher prevalence of dogs with mixed infestations in rural than urban areas.

This study shows that fleas and ticks in domestic dogs are fairly abundant across Chile and that there is not a clear pattern of a dominance of one flea or tick species over the others, but there is local variation in the pattern of infestation. Former suggest that there are other factors implicated in the infestation of fleas and tick species beside than merely the place where dogs inhabit (i.e. anti-parasite treatment, dogs allowing to roam freely, etc.), which clearly need to be assessed, along with pathogens transmitted for these vectors.

\section{ACKNOWLEDGEMENTS}

This study was financially supported by FONDECYT Projects $\mathrm{N}^{\circ} 1100809,1130817$ and 11100303 . We also thank Paulina Lepe for determining the taxonomy of fleas and ticks.

\section{REFERENCES}

Abarca K, J López, G Acosta-Jamett, P Lepe, JF Soares, MB Labruna. 2012. A third Amblyomma species and the first tick-borne rickettsia in Chile. J Med Entomol 49, 219-222.

Abarca K, J López, G Acosta-Jamett, C Martínez-Valdebenito. 2013. Detection of Rickettsia andeanae in two regions of Chile. Rev Chilena Infectol 30, 388-394.

Acosta-Jamett G, S Cleaveland, A Cunningham, M Bronsvoort. 2010. Demography of domestic dogs in rural and urban areas in Coquimbo region of Chile and its implication for diseases transmission. Prev Vet Med 94, 272-281.

Alcaíno HA. 1985. Antecedentes sobre la garrapata café del perro (Rhipicephalus sanguineus). Monog Med Vet 7, 48-55.

Alcaíno H, T Gorman. 1999. Parásitos de los animales domésticos en Chile. Parasitol Día 23, 33-41.

Alcaíno HA, TR Gorman, R Alcaino. 2002. Flea species from dogs in three cities of Chile. Vet Parasitol 105, 261-265.

Barros-Battesti DM, M Arzua, GH Bechara. 2006. Carrapatos de Importância Médico-Veterinária da Região Neotropical: Um guia ilustrado para identificação de espécies. Vox/ICTTD-3/Butantan, São Paulo, Brasil.

Beck W, K Boch, H Mackensen, B Wiegand, K Pfister. 2006. Qualitative and quantitative observations on the flea population dynamics of dogs and cats in several areas of Germany. Vet Parasitol 137, 130-136.

Costa AP, AB Silva, FB Costa, GS Xavier, TF Martins, MB Labruna, RM Guerra. 2013. A survey of ectoparasites infesting urban and rural dogs of Maranhão state, Brazil. J Med Entomol 50, 674-678.

Dantas-Torres F, MF Melo, LA Figueredo, SP Brandao-Filho. 2009. Ectoparasite infestation on rural dogs in the municipality of Sao Vicente Ferrer, Pernambuco, Northeastern Brazil. Rev Bras Parasitol Vet 18, 75-77.

Dantas-Torres F. 2010. Biology and ecology of the brown dog tick, Rhipicephalus sanguineus. Parasite Vector 3, 26.

Debárbora VN, EB Oscherov, AA Guglielmone, S Nava. 2011. Garrapatas (Acari: Ixodidae) asociadas a perros en diferentes ambientes de la provincia de Corrientes, Argentina. InVet 13, 45-51.

Durden LA, NC Hinkle. 2009. Fleas (Siphonaptera), In: Mullen GR, Durden LA (eds). Medical and Veterinary Entomology. Academic Press, San Diego, USA, Pp 110-130.

Durden LA, TN Judy, JE Martin, LS Spedding. 2005. Fleas parasitizing domestic dogs in Georgia, USA: Species composition and seasonal abundance. Vet Parasitol 130, 157-162.

Estrada-Peña A, JM Venzal, AJ Mangold, MM Cafrune, AA Guglielmone. 2005. The Amblyomma maculatum Koch, 1844 (Acari: Ixodidae: 
Amblyomminae) tick group: diagnostic characters, description of the larva of $A$. parvitarsum Neumann, 1901, 16S rDNA sequences, distribution and hosts. Syst Parasitol 60, 99-112.

Farkas R, M Gyurkovszky, N Solymosi, F Beugnet. 2009. Prevalence of flea infestation in dogs and cats in Hungary combined with a survey of owner awareness. Med Vet Entomol 23, 187-194.

González A, C Del Castro, S González. 2004. Ectoparasitic species from Canis familiaris (Linne) in Buenos Aires province, Argentina. Vet Parasitol 120, 123-129.

González-Acuña D, J Venzal, O Skewes-Ramm, L Rubilar-Contreras, A Daugschies, AA Guglielmonte. 2004. First record of immature stages of Amblyomma tigrinum (Acari : Ixodidae) on wild birds in Chile. Exp Appl Acarol 33, 153-156.

González-Acuña D, AA Guglielmone. 2005. Ticks (Acari: Ixodoidea: Argasidae, Ixodidae) of Chile. Exp Appl Acarol 35, 147-163.

Gracia MJ, C Calvete, R Estrada, JA Castillo, MA Peribanez, J Lucientes. 2008. Fleas parasitizing domestic dogs in Spain. Vet Parasitol 151, 312-319.

Hugh-Jones ME, WT Hubbert, HV Hagstad, 2000. Zoonoses: recognition, control, and prevention. Iowa State University Press, Ames, USA.

INE, Instituto Nacional de Estadísticas. 2005. Censo 2002. Resultados población y vivienda. INE, Santiago, Chile.

Labruna MB, VS Homem, MB Heinemann, JS Ferreira Neto. 2000. Ticks (Acari: Ixodidae) associated with rural dogs in Uruara, eastern Amazon, Brazil. J Med Entomol 37, 774-776.

Labruna MB, EY Fugisaki, A Pinter, JM Duarte, MJ Szabo. 2003. Life cycle and host specificity of Amblyomma triste (Acari: Ixodidae) under laboratory conditions. Exp Appl Acarol 30, 305-316.

Mastropaolo M, V Orcellet, AA Guglielmone, AJ Mangold. 2008. Ixodes pararicinus Keirans \& Clifford 1985 y Amblyomma tigrinum Koch, 1884 (Acari: Ixodidae): nuevos registros para Argentina y Chile. Rev FAVE-Cienc Vet 7, 67-70.
Muñoz L, ME Casanueva. 2002. Ticks (Acari : Ixodidae) on dogs in Concepcion city, Chile. Arch Med Vet 34, 131-134.

Nava S, JA Caparros, AJ Mangold, AA Guglielmone. 2006. Ticks (Acari: Ixodida: Argasidae, Ixodidae) infesting humans in Northwestern Cordoba Province, Argentina. Medic (B Aires) 66, 225-228.

Neves L, S Afonso, IG Horak. 2004. Ixodid ticks on dogs in southern Mozambique. Onderstepoort J Vet Res 71, 279-283.

Otranto D, R Wall. 2008. New strategies for the control of arthropod vectors of disease in dogs and cats. Med Vet Entomol 22, 291-302.

Paddock CD, JW Sumner, JA Comer, SR Zaki, CS Goldsmith, J Goddard, SL McLellan, CL Tamminga, CA Ohl. 2004. Rickettsia parkeri: a newly recognized cause of spotted fever rickettsiosis in the United States. Clin Inf Dis 38, 805-811.

Pratt HD, CHJ Stojanovich. 1966. Fleas. Illustrated key to species found during plague investigations. In: US Department of Health, Education and Welfare (ed). Pictorial Keys: Arthropods, Reptiles, Birds and Mammals of Public Health Significance. Public Health Service, Communicable Disease Center, Atlanta, GA, USA, Pp 171-174.

Shaw SE, MJ Day, RJ Birtles, EB Breitschwerdt. 2001. Tick-borne infectious diseases of dogs. Trends Parasitol 17, 74-80.

Shimada Y, T Beppu, H Inokuma, M Okuda, T Onishi. 2003. Ixodid tick species recovered from domestic dogs in Japan. Med Vet Entomol 17, 38-45.

Szabo MP, TM Cunha, A Pinter, F Vicentini. 2001. Ticks (Acari: Ixodidae) associated with domestic dogs in Franca region, Sao Paulo, Brazil. Exp Appl Acarol 25, 909-916.

Tagle L. 1971. Ixodoidea in Chile. Bol Chil Parasitol 26, 46-49.

Tagle L. 1976. Presencia accidental de Rhipicephalus sanguineus en un perro de Santiago de Chile. Agric Téc (Chile) 36, 137.

Venzal JM, A Estrada-Peña, O Castro, CG de Souza, ML Felix, S Nava, AA Guglielmone. 2008. Amblyomma triste Koch, 1844 (Acari: Ixodidae): hosts and seasonality of the vector of Rickettsia parkeri in Uruguay. Vet Parasitol 155, 104-109. 